\title{
BATCH ADSORPTION STUDIES FOR MALACHITE GREEN DYE REMOVAL FROM WASTE WATER USING BIOMASS BASED ADSORBENT
}

\author{
Sunanda Sharma1, sunanda9@gmail.com \\ K.K. Pant ${ }^{2}$,kkpant@chemical.iitd.ac.in \\ D.P.Tiwari ${ }^{1}$,dptiwari3@gmail.com \\ ${ }^{1}$ Deenbandhu Chhotu Ram University of Science and Technology, Murthal, India \\ ${ }^{2}$ Indian Institute of Technology, Delhi, India
}

\begin{abstract}
Adsorption of malachite green dye over the adsorbents (Ad) derived from Sapindus seed hull (S) and Camelina (C) after treatment with sulphuric acid is studied. Batch adsorption study on both Ad is compared as a function of various parameters such as $\mathrm{pH}$, time, initial concentration and temperature. The isotherm data is found to be best presented by Langmuir model for both adsorbents. Separation factor $\left(\mathrm{R}_{\mathrm{L}}\right)$ revealed a favorable adsorption. Further, the rate of adsorption followed pseudo-first order kinetics. The intraparticle diffusion model facilitates to understand mass transfer in adsorption of dye molecules. Thermodynamic analysis on both Ad revealed the spontaneity of the phenomena at higher temperature. The comparative study illustrated higher adsorption capacity of CAd in comparison to SAd.
\end{abstract}

Keywords: Adsorption, malachite green, Sapindus, and Camelina.

\section{Introduction}

The effluents discharged from industries mainly involved in the manufacturing of textiles, paper, plastic, leather, etc. contains different dyes which pollutes water resources. These dyes are highly harmful for the health of living species [1]. Among all Malachite green is one of such dye which cause several health hazards to human. It is very toxic and carcinogenic in nature [2-9]. For the removal of dyes from the waste liquid, researchers investigated various physical, chemical and biological methods [1012]. Among all those quoted methods, adsorption has been found to be the most attractive method due to its simplicity. In this method, the effluent is separated from the liquid using adsorbent derived from various sources. Commercially, the adsorbents are derived from natural sources like wood and coal which are very expensive $[13,14]$. As a result, the separation of these effluents becomes cost intensive. Hence, the derivation of adsorbent shall be made cost effective. This can be achieved by either exploring adsorption process or using cost effective feedstock. In last couple of years, biowaste based feed stock materials like agricultural byproducts olive stones, hen feathers, tuncbilek lignite, wheat bran, rice bran, arundodonax root, pine saw dust, jute fibers, rice husk, bamboo, chitosan beads, marine alga, neem sawdust, borassus flower, coconut fiber, baggas, soyabean and oil palm fiber have been tried [4,9,12,15-24]. However, the potential of other bio-wastes like Sapindus seed hull and Camelina has not been studied. This work, therefore, presents a study for the production of low cost adsorbent from these two bio-waste feed-stocks and application in the removal of malachite green from the waste water. Further, the adsorption capacity of SAd and CAd is compared with other low cost adsorbents as quoted in the literature.

\section{Experimental}

Preparation: Sapindus seed hulls (S) and Camelina (C) were dried and crushed to powder of desired size. A fixed amount of both the raw materials were then mixed separately with concentrated sulphuric acid in 1:2 weight ratio. The adsorbents thus prepared were then washed with distilled water and soaked in $1 \% \mathrm{NaHCO}_{3}$ solution overnight to neutralize the free acid. Again, both the adsorbents were washed with distilled water till $\mathrm{pH}$ reaches $6-7$ and dried in an air oven at $120^{\circ} \mathrm{C}$ for $4 \mathrm{~h}$. The Sapindus and Camelina based activated carbon adsorbents were named as SAd and CAd, respectively. The final particle size of both the adsorbents before adsorption studies was maintained to $150 \mu \mathrm{m}$ by crushing.

CHNS analysis was done using CHNS analyser (vario MACRO cube); a sample weighing up to $200 \mathrm{mg}$ was heated to $1200^{\circ} \mathrm{C}$. Helium gas draw on as a carrier gas. 


\section{Физическая химия}

Adsorbate: Malachite green supplied by Thermofischer was used as such without any treatment. Distilled water was prepared by borosilicate distillation unit indigenously and used for the preparation of solutions. Initially, a stock solution of $100 \mathrm{mg} \cdot \mathrm{L}^{-1}$ was prepared and remaining working solutions were prepared by dilution.

Adsorption studies: The adsorption isotherms and kinetics studies were carried out in batch wise fashion. Equilibrium study was conducted by taking $50 \mathrm{ml}$ of different concentrations $\left(10-100 \mathrm{mg} \cdot \mathrm{L}^{-1}\right)$ of malachite green solution at $\mathrm{pH} 6$ and $100 \mathrm{mg}$ of $\mathrm{AC}$ was added. The mixture was then stirred for 360 $\min$ at $120 \mathrm{rpm}$ to ensure equilibrium. The solution concentration was analyzed through uv-vis spectrophotometer (Varian Carry-100) at $617 \mathrm{~nm}$. The amount of adsorption $\left(\mathrm{q}_{\mathrm{e}}\right)$ at equilibrium was calculated as:

$$
\mathrm{q}_{\mathrm{e}}=\frac{\left(\mathrm{C}_{\mathrm{i}}-\mathrm{C}_{\mathrm{e}}\right) \times \mathrm{V}}{\mathrm{m}}
$$

where $m$ is the mass of dry adsorbent used $(g), C_{i}-$ initial and $C_{e}-$ equilibrium concentration $\left(\mathrm{mg} \cdot \mathrm{L}^{-1}\right)$ of malachite green. The same expression was used for kinetics studies by replacing $\mathrm{q}_{e}$ and $\mathrm{C}_{\mathrm{e}}$ with $\mathrm{q}_{\mathrm{t}}$ and $\mathrm{C}_{\mathrm{t}}$, respectively.

Kinetic studies were carried out in the similar fashion with those of equilibrium experiments, wherein the samples were taken at different time intervals and analyzed as above. Four different concentrations of malachite green solutions $\left(10,40,70\right.$ and $\left.100 \mathrm{mg} \cdot \mathrm{g}^{-1}\right)$ were taken for the kinetic analysis at three different temperatures 30,40 , and $50^{\circ} \mathrm{C}$.

\section{Results and Discussion}

Table 1 presents CHNSO content of all the four samples, where, ' $\mathrm{O}$ ' content was calculated on the difference basis as: $\mathrm{O}, \%=100-(\mathrm{C} \%+\mathrm{H} \%+\mathrm{N} \%+\mathrm{S} \%)$. $\mathrm{H} / \mathrm{C}$ ratio depicts significant fall in both $\mathrm{CAd}$ and SAd in contrast to their respective precursors. It has been observed that although sample $\mathrm{S}$ is richer in carbon content than C; yet, CAd has shown greater extent of enrichment than SAd. The reason is the ease of volatiles excursion in the case of sample C; sapindus seeds are hard and the escalation of volatiles is not that much easier. This finding facilitates to understand the better adsorption ability of CAd in comparison to SAd.

CHNSO composition and $\mathrm{H} / \mathrm{C}$ ratioof $\mathrm{C}, \mathrm{S}, \mathrm{CAd}$ and Sad

Table 1

\begin{tabular}{|l|l|l|l|l|l|l|}
\hline Sample & $\mathrm{C}, \%$ & $\mathrm{H}, \%$ & $\mathrm{~N}, \%$ & $\mathrm{~S}, \%$ & $\mathrm{O}, \%$ & $\mathrm{H} / \mathrm{C}$ \\
\hline C & 38.90 & 5.88 & 0.71 & 0.17 & 54.35 & 0.15 \\
\hline CAd & 51.93 & 2.55 & 0.15 & 0.27 & 45.10 & 0.05 \\
\hline S & 43.67 & 6.02 & 0.44 & 0.06 & 49.81 & 0.14 \\
\hline SAd & 49.77 & 2.54 & 0.36 & 0.82 & 46.51 & 0.05 \\
\hline
\end{tabular}

The study of temperature effect on adsorption facilitates evaluation of thermodynamic parameters including enthalpy change, entropy change, Gibbs free energy likewise [25]. So, temperature dependent study was performed for malachite green dye adsorption at 30,40 and $50^{\circ} \mathrm{C}$. The extent of adsorption on CAdand SAdis presented in the Fig. 1 where each curve represent a study at particular temperature. Both materials proved higher percent of dye removal with increase in temperature. The percent dye removal from solution at $30^{\circ} \mathrm{C}$ by SAd and CAd are found to be 6.5 and $19.5 \%$, respectively, at initial concentration of $100 \mathrm{mg} \cdot \mathrm{L}^{-1}$. These values, further, increased up to 19.5 and $30.8 \%$ for SAd and CAd, respectively, with increase in temperature to $50^{\circ} \mathrm{C}$. This is clear from the experimental data that at higher temperature dye molecules must have been excited enough to reach adsorption site. Further, it is expected that a fall in viscosity of the solution at higher temperature improves boundary layer diffusion [10].

It is important to study the effect of initial concentration on the adsorption rate. This study proves that at higher concentration the uptake of dye molecules increased for both CAd and SAd. The initial concentration provides driving force between aqueous solution and adsorbent [26]. At every temperature the same finding is observed. Although, the percent removal shows a drop in value due to the saturation of active sites in solid substrate; the uptake in $\mathrm{mg} \cdot \mathrm{g}^{-1}$ improves. 

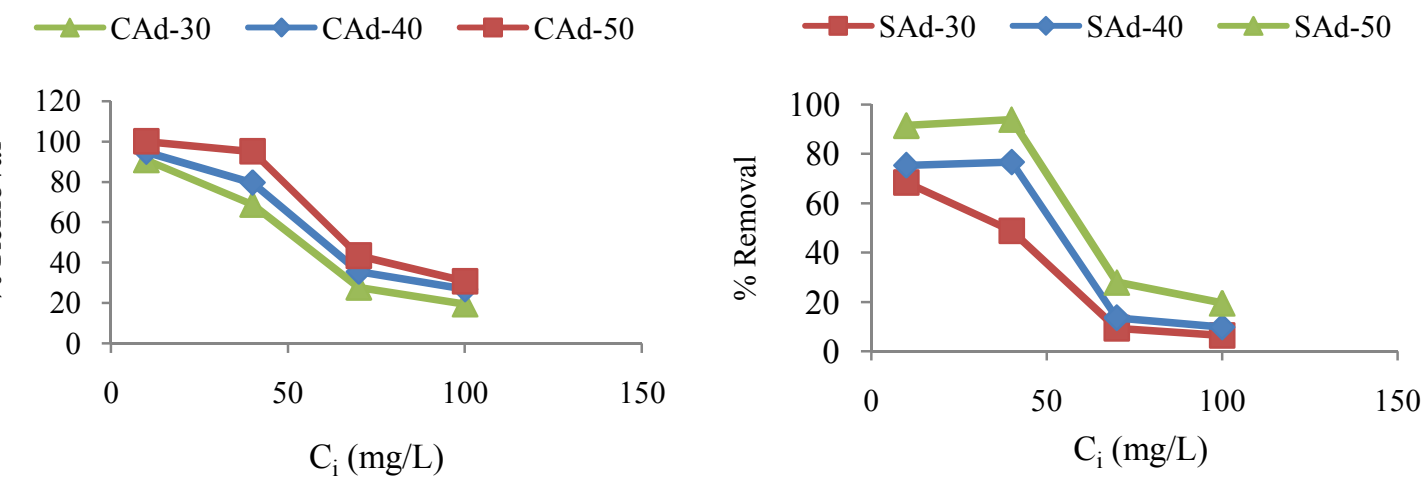

Fig. 1. Different curves at temperatures 30,40 and $50^{\circ} \mathrm{C}$

The $\mathrm{pH}$ of solution affects degree of ionization and hence, the extent of adsorption as explained [25]. In case of CAd, the adsorption uptake is found to increase from 12.7 to $20.6 \mathrm{mg} \cdot \mathrm{g}^{-1}$ when $\mathrm{pH}$ of aqueous solution changes from 2 to 6 as shown in Fig. 2. Alike trend has been reported elsewhere [27]. It, further, dropped to $18.4 \mathrm{mg} \cdot \mathrm{g}^{-1}$ as $\mathrm{pH}$ is increased from 6 to 10 . Similarly, $\mathrm{q}_{\mathrm{e}}$ for SAd increases from 9.2 to $14.7 \mathrm{mg} \cdot \mathrm{g}^{-1}$ with an increase in $\mathrm{pH}$ from 2 to 6 . Again, $\mathrm{q}_{\mathrm{e}}$ lowered to $12.4 \mathrm{mg} \cdot \mathrm{g}^{-1}$ as $\mathrm{pH}$ exceeds 6 up to 10. Analogous behavior has been reported in the literature [10]. It proves that $\mathrm{pH}$ influence the surface charge of the adsorbents.

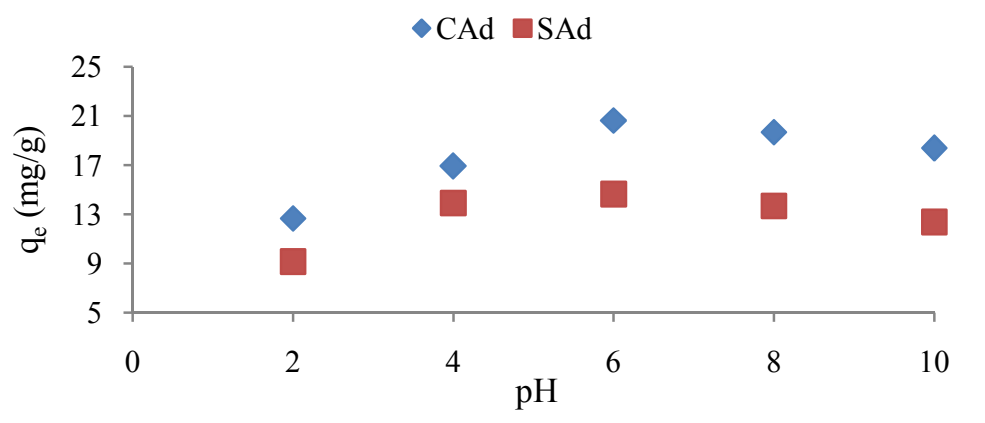

Fig. 2. Effect of $\mathrm{pH}$ of malachite green dye solution on the adsorption at $30^{\circ} \mathrm{C}$

The effect of contact time on adsorption of malachite green is shown in Fig. 3 for CAd and SAd. It is clear from the figure that initially adsorption takes place at faster rate and after $150 \mathrm{~min}$ this rate slows down. The reason behind so is the availability of numerous sites for dye molecules to get adsorbed at an early stages of adsorption [10]. Later, decrease in diffusion rate as well as concentration gradient results in slow down of adsorption as mentioned [28]. Both adsorbents showed an equilibration state after $180 \mathrm{~min}$. Further, Fig. 3 depicts the possibility of monolayer adsorption of dye molecules due the smoothness and continuity of the curve [29].

$\diamond \mathrm{CAd} \square \mathrm{SAd}$

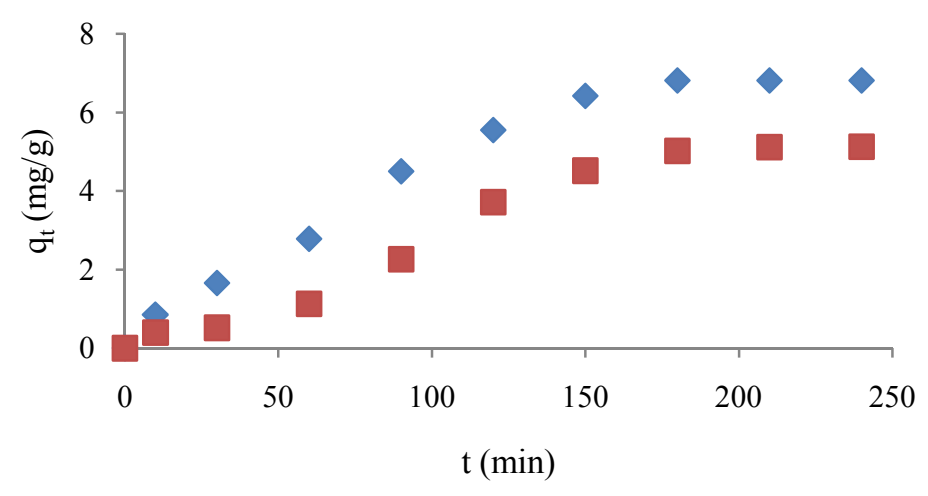

Fig. 3. Effect of contact time on the adsorption of malachite green at $30^{\circ} \mathrm{C}$ 
The adsorption isotherm tells the distribution of adsorbate in solid to liquid phase and hence, presents a relation among the quantity adsorbed $\mathrm{q}_{\mathrm{e}}$ to the concentration in the solution at equilibrium, $\mathrm{C}_{\mathrm{e}}$. Among the various models in literature, the most commonly employed are Langmuir and Freundlich models. Langmuir model is used to understand the equilibrium with an important assumption of homogeneity of adsorption on the surface. The mathematical expression of Langmuir model is presented below [10]:

$$
\frac{\mathrm{C}_{\mathrm{e}}}{\mathrm{q}_{\mathrm{e}}}=\frac{1}{\mathrm{~K}_{\mathrm{L}} \mathrm{q}_{\max }}+\frac{1}{\mathrm{q}_{\max }} \mathrm{C}_{\mathrm{e}}
$$

where, $\mathrm{q}_{\mathrm{e}}$ is the amount of adsorbate adsorbed $\left(\mathrm{mg} \cdot \mathrm{g}^{-1}\right)$ at equilibrium and evaluated as presented elsewhere, $C_{e}$ is the concentration at equilibrium $\left(\mathrm{mg} \cdot \mathrm{L}^{-1}\right), \mathrm{q}_{\max }$ represents monolayer capacity $\left(\mathrm{mg} \cdot \mathrm{g}^{-1}\right)$ and $\mathrm{K}_{\mathrm{L}}$ in the above equation corresponds to adsorption equilibrium constant $\left(\mathrm{L} \cdot \mathrm{mg}^{-1}\right)$. A graph between $\mathrm{C}_{\mathrm{e}} / \mathrm{q}_{\mathrm{e}}$ versus $\mathrm{C}_{\mathrm{e}}$ yields a straight line as shown in Fig. 4. The slope and intercept of this line produces $\mathrm{q}_{\max }$ and $\mathrm{K}_{\mathrm{L}}$ values and are presented in Table 2 .
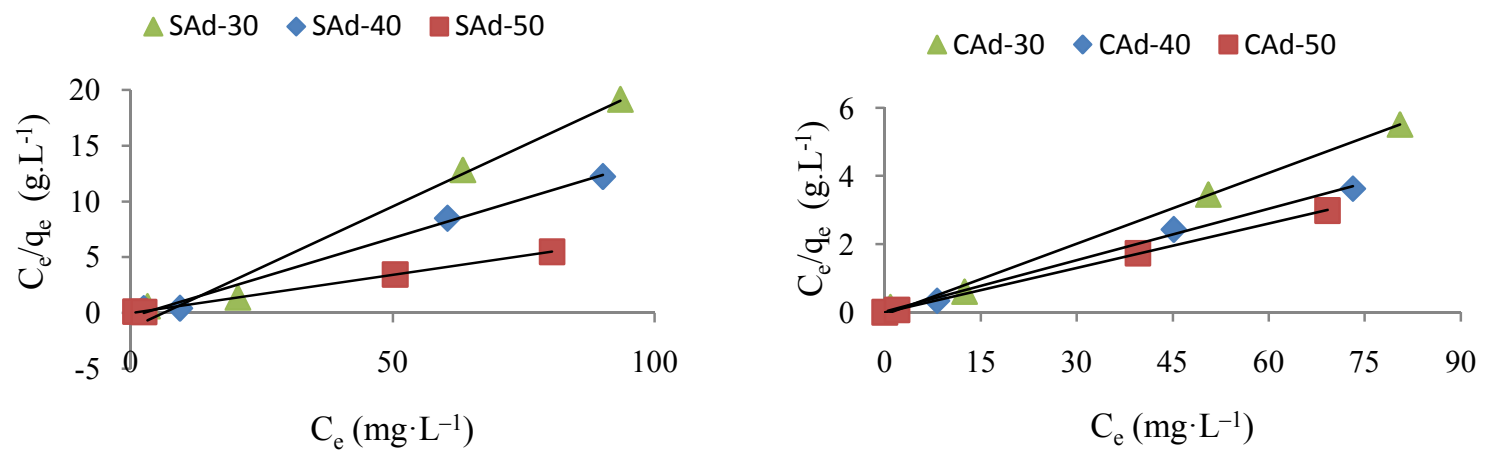

Fig. 4. Langmuir isotherms for CAd and SAd at temperatures 30,40 and $50^{\circ} \mathrm{C}$ for initial concentration $40 \mathrm{mg} \cdot \mathrm{L}^{-1}$

It has been observed that $\mathrm{q}_{\max }$ for CAd and SAd increases from 14.41 to 23.04 and 4.83 to $14.64 \mathrm{mg} \cdot \mathrm{g}^{-1}$, respectively, when temperature was raised from 30 to $50^{\circ} \mathrm{C}$. This proves that higher temperature favors adsorption of malachite green on $\mathrm{C}$ and $\mathrm{S}$ derived adsorbents. Some lesser value of adsorption capacity has already been reported elsewhere $[1,7,19,29,30]$. Further, $\mathrm{K}_{\mathrm{L}}$ values at $30^{\circ} \mathrm{C}$ are found to be 0.92 and $0.59 \mathrm{~L} \cdot \mathrm{mg}^{-1}$ for CAd and SAd, respectively, and found to be raised to 1.85 and $11.78 \mathrm{~L} \cdot \mathrm{mg}^{-1}$, respectively, at $50^{\circ} \mathrm{C}$. Separation factor, $\mathrm{R}_{\mathrm{L}}$ indicates the nature of adsorption process and is evaluated using the relation as stated in [10]:

$$
\mathrm{R}_{\mathrm{L}}=\frac{1}{1+\mathrm{K}_{\mathrm{L}} \mathrm{C}_{\mathrm{o}}}
$$

Here, $C_{o}$ is the highest initial dye concentration. $R_{L}$ value between 0 and 1 signifies a favorable process of dye adsorption. During the adsorption of malachite green on CAd and SAd, this value varies within the range $0.0107-0.0009$ and $0.0167-0.0008$, respectively, at all temperatures under study.

Equilibrium models constants for the adsorption of malachite green on CAd and SAd

Table 2

\begin{tabular}{|c|c|c|c|c|c|c|c|}
\hline \multirow{2}{*}{ Isotherm } & \multirow{2}{*}{ Parameters } & \multicolumn{3}{|c|}{ CAd } & \multicolumn{3}{c|}{$\mathrm{SAd}$} \\
\cline { 2 - 8 } & & $303 \mathrm{~K}$ & $313 \mathrm{~K}$ & $323 \mathrm{~K}$ & $303 \mathrm{~K}$ & $313 \mathrm{~K}$ & $323 \mathrm{~K}$ \\
\hline \multirow{4}{*}{ Langmuir } & $\mathrm{q}_{\max }\left(\mathrm{mg} \cdot \mathrm{g}^{-1}\right)$ & 14.41 & 19.80 & 23.04 & 4.83 & 7.09 & 14.64 \\
\cline { 2 - 8 } & $\mathrm{K}_{\mathrm{L}}\left(\mathrm{L} \cdot \mathrm{mg}^{-1}\right)$ & 0.92 & 3.28 & 1.85 & 0.59 & 0.41 & 11.78 \\
\cline { 2 - 8 } & $\mathrm{R}_{\mathrm{L}}$ & 0.0107 & 0.0030 & 0.0009 & 0.0167 & 0.0235 & 0.0008 \\
\cline { 2 - 8 } Freundlich & $\mathrm{R}^{2}$ & 0.9970 & 0.9965 & 0.9999 & 0.9807 & 0.9941 & 0.9995 \\
\cline { 2 - 8 } & $\mathrm{K}_{\mathrm{f}}\left(\mathrm{mg} \cdot \mathrm{g}^{-1}\right) \cdot\left(\mathrm{L} \cdot \mathrm{mg}^{-1}\right)^{1 / 1}$ & 8.33 & 9.85 & 17.57 & 7.51 & 10.06 & 12.36 \\
\cline { 2 - 8 } & $\mathrm{n}$ & 5.89 & 4.99 & 9.58 & -22.78 & 28.99 & 15.77 \\
\cline { 2 - 8 } & $1 / \mathrm{n}$ & 0.17 & 0.20 & 0.10 & -0.04 & -0.03 & 0.06 \\
\cline { 2 - 8 } & $\mathrm{R}^{2}$ & 0.5298 & 0.6749 & 0.7889 & 0.0600 & 0.0085 & 0.0153 \\
\hline
\end{tabular}


The following linear expression for Freundlich isotherm is used [10]:

$$
\log q_{e}=\log K_{f}+\frac{1}{n} \log C_{e}
$$

where, $\mathrm{K}_{\mathrm{f}}\left(\mathrm{mg} \cdot \mathrm{g}^{-1} \cdot\left(\mathrm{mg} \cdot \mathrm{L}^{-1}\right)^{1 / \mathrm{n}}\right)$ and $\mathrm{n}$ represents bonding energy [28] and process favorability, respectively. Freundlich constants, $\mathrm{K}_{\mathrm{f}}$ and $\mathrm{n}$ are evaluated from the plot between $\log \mathrm{q}_{\mathrm{e}}$ and $\log \mathrm{C}_{\mathrm{e}}$ as shown in Fig. 5 and are reported in Table 2 for CAd and SAd. It is found that temperature has positively affected and resulted in the rise of both constants $\mathrm{K}_{\mathrm{f}}$ and $\mathrm{n}$ for CAd as well as SAd. The value of $\mathrm{n}>1$ indicates that the dye is favorably adsorbed favoring normal Langmuir isotherm on CAd and SAd. The correlation coefficient, $\mathrm{R}^{2}$ close to 1 depicts best fit of the equilibrium model. In this study, Langmuir model is best fitted to the equilibrium data for the malachite green dye adsorption on both adsorbents CAd and SAd.

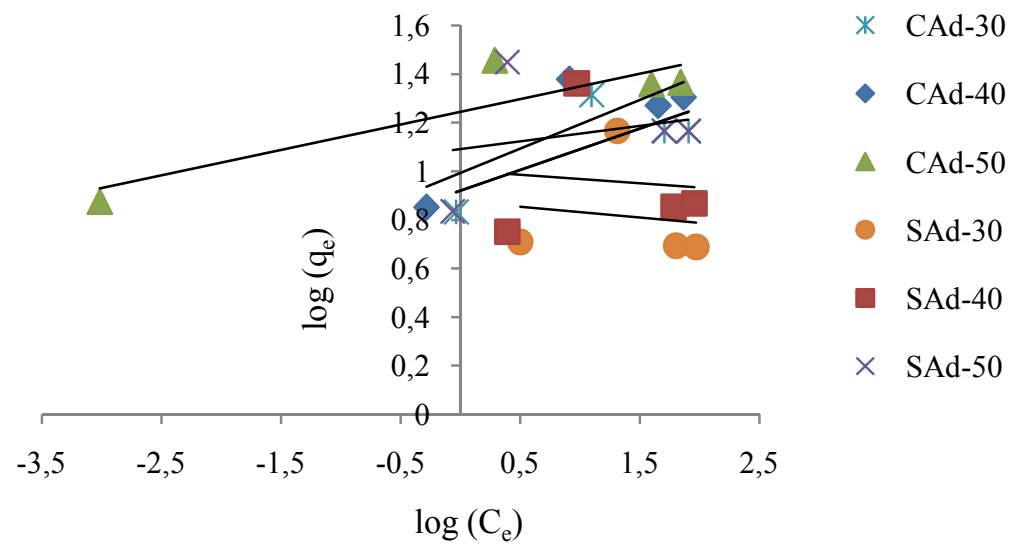

Fig. 5. Freundlich isotherms for CAd and SAd at temperatures 30,40 and $50^{\circ} \mathrm{C}$ for initial concentration $40 \mathrm{mg} \cdot \mathrm{L}^{-1}$

In order to understand the controlling step involved in the adsorption of malachite green such as diffusion, adsorption and chemical reaction; various kinetic models are employed to the experimental results. The pseudo-first-order expression is presented below:

$$
\ln \left(\mathrm{q}_{\mathrm{e}}-\mathrm{q}_{\mathrm{t}}\right)=\ln \mathrm{q}_{\mathrm{e}}+\mathrm{k}_{1} \mathrm{t}
$$

where, $\mathrm{q}_{\mathrm{e}}$ and $\mathrm{q}_{\mathrm{t}}$ represents amount of dye adsorbed at equilibrium and at time, $\mathrm{t}$; both in $\mathrm{mg} \cdot \mathrm{g}^{-1}$. The first order rate constant, $\mathrm{k}_{1}\left(\mathrm{~min}^{-1}\right)$ is evaluated from the slope of straight line between $\ln \left(\mathrm{q}_{\mathrm{e}}-\mathrm{q}_{\mathrm{t}}\right)$ and $\mathrm{t}$ as shown in Fig. 6. The values of parameters $\mathrm{k}_{1}, \mathrm{q}_{\mathrm{e}}$ and $\mathrm{R}^{2}$ at different initial concentrations are listed in Table 3. The values of $\mathrm{R}^{2}$ are found to be inconsistent and so, concluded that adsorption of malachite green dye does not follow pseudo-first-order kinetic model.
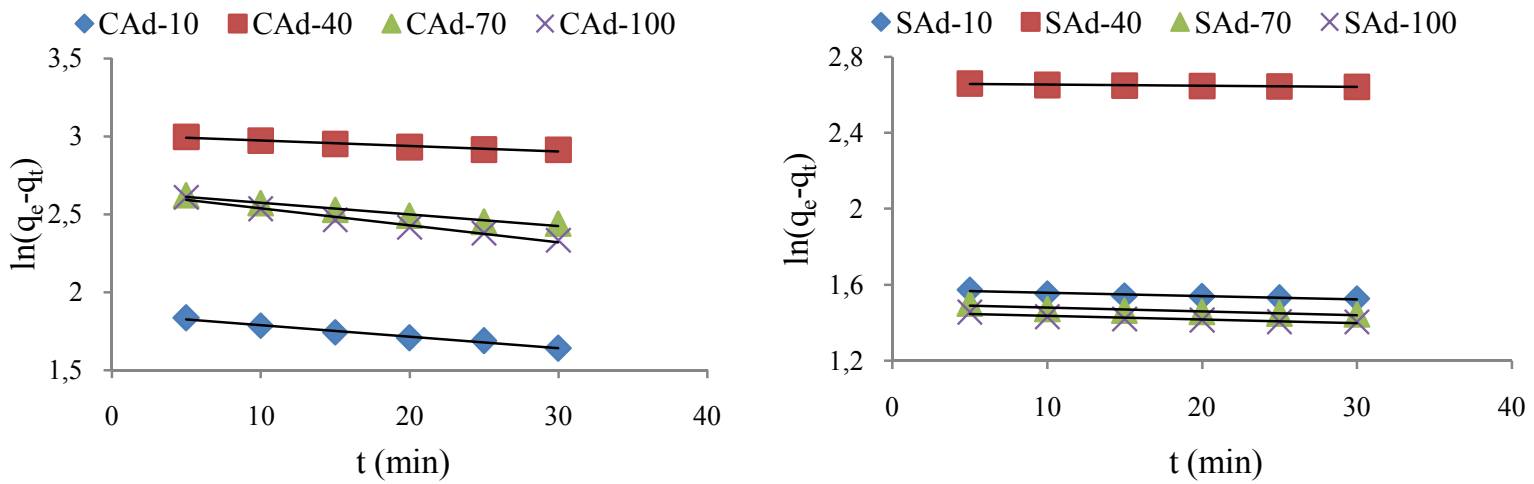

Fig. 6. Pseudo-first-order kinetic model for (a) CAd and (b) SAd for different initial concentrations - 10, 40, 70 and $100 \mathrm{mg} \cdot \mathrm{L}^{-1}$ at $30^{\circ} \mathrm{C}$ 
Kinetic models and diffusion model constants for adsorption of malachite green on CAd and SAd at $30^{\circ} \mathrm{C}$

\begin{tabular}{|c|c|c|c|c|c|c|}
\hline \multicolumn{3}{|c|}{$\mathrm{C}_{\mathrm{i}}\left(\mathrm{mg} \cdot \mathrm{L}^{-1}\right)$} & 10 & 40 & 70 & 100 \\
\hline \multirow{6}{*}{$\begin{array}{l}\text { Pseudo-first-order kinetic } \\
\text { model }\end{array}$} & \multirow{2}{*}{$\begin{array}{l}\mathrm{k}_{1} \cdot 10^{2} \\
\left(\min ^{-1}\right) \\
\end{array}$} & SAd & 0.18 & 0.06 & 0.21 & 0.2 \\
\hline & & CAd & 0.74 & 0.35 & 0.75 & 1.08 \\
\hline & \multirow{2}{*}{$\begin{array}{c}\mathrm{q}_{\mathrm{e}} \\
\left(\mathrm{mg} \cdot \mathrm{g}^{-1}\right)\end{array}$} & SAd & 4.83 & 14.3 & 4.48 & 4.29 \\
\hline & & CAd & 6.44 & 20.24 & 14.13 & 14.1 \\
\hline & \multirow{2}{*}{$\mathrm{R}^{2}$} & SAd & 0.906 & 0.916 & 0.895 & 0.886 \\
\hline & & CAd & 0.986 & 0.956 & 0.972 & 0.979 \\
\hline \multirow{6}{*}{$\begin{array}{l}\text { Pseudo-second-order } \\
\text { kinetic model }\end{array}$} & \multirow{2}{*}{$\begin{array}{c}\mathrm{k}_{2} \\
\left(\mathrm{~g} \cdot \mathrm{mg}^{-1} \cdot \min ^{-1}\right)\end{array}$} & SAd & 0.31 & 0.31 & 0.34 & 0.44 \\
\hline & & CAd & 0.018 & 0.006 & 0.003 & 0.002 \\
\hline & \multirow{2}{*}{$\begin{array}{c}\mathrm{q}_{2} \\
\left(\mathrm{mg} \cdot \mathrm{g}^{-1}\right)\end{array}$} & SAd & 0.61 & 0.68 & 0.79 & 0.88 \\
\hline & & CAd & 2.69 & 5.05 & 7.45 & 11.52 \\
\hline & \multirow{2}{*}{$\mathrm{R}^{2}$} & SAd & 0.973 & 0.955 & 0.969 & 0.934 \\
\hline & & CAd & 0.999 & 0.999 & 0.999 & 0.999 \\
\hline \multirow{4}{*}{$\begin{array}{l}\text { Intra-particle diffusion } \\
\text { model }\end{array}$} & \multirow{2}{*}{$\begin{array}{c}\mathrm{C} \\
\left(\mathrm{mg} \cdot \mathrm{g}^{-1}\right) \\
\end{array}$} & SAd & 0.05 & 0.07 & 0.09 & 0.14 \\
\hline & & CAd & 0.06 & 0.16 & 0.24 & 0.35 \\
\hline & \multirow{2}{*}{$\begin{array}{c}\mathrm{K}_{\mathrm{P}} \\
\left(\mathrm{mg} \cdot \mathrm{g}^{-1} \cdot \min ^{-1}\right)\end{array}$} & SAd & 0.09 & 0.11 & 0.13 & 0.14 \\
\hline & & CAd & 0.29 & 0.44 & 0.61 & 0.82 \\
\hline
\end{tabular}

The pseudo-second-order kinetic model is presented below:

$$
\frac{\mathrm{t}}{\mathrm{q}_{\mathrm{t}}}=\frac{1}{\mathrm{k}_{2} \mathrm{q}_{\mathrm{e}}^{2}}-\frac{1}{\mathrm{q}_{\mathrm{e}}} \mathrm{t}
$$

where, $\mathrm{q}_{\mathrm{e}}$ represents maximum adsorption in $\mathrm{mg} \cdot \mathrm{g}^{-1}$ through second order adsorption kinetics and $\mathrm{k}_{2}$ is the rate constant at equilibrium in $\mathrm{g} \cdot(\mathrm{mg} \cdot \mathrm{min})^{-1}$. Both parameters $-\mathrm{q}_{\mathrm{e}}$ and $\mathrm{k}_{2}$ are evaluated from the plot between $t / q_{t}$ and $t$ as shown in Fig. 7 and are presented in Table 3 at various initial concentrations. The correlation coefficient $\mathrm{R}^{2}$ for pseudo-second-order kinetic model is close to unity; this implies that adsorption phenomenon is best represented by second-order mechanism. Alike results for pseudo-second order kinetics are presented elsewhere [10].
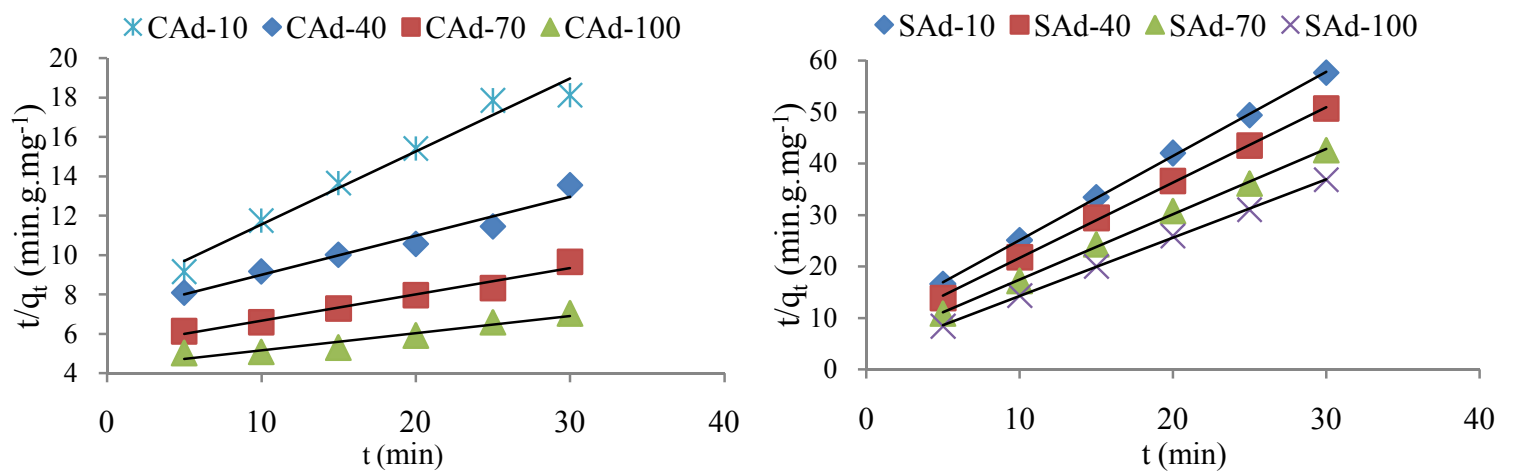

Fig. 7. Pseudo-second-order kinetic model for CAd and SAd for different initial concentrations - 10, 40, 70 and $100 \mathrm{mg} \cdot \mathrm{L}^{-1}$ at $30^{\circ} \mathrm{C}$

To study the mechanism of intraparticle diffusion Weber and Morris model is used:

$$
\mathrm{q}_{\mathrm{t}}=\mathrm{K}_{\mathrm{p}} \mathrm{t}^{0.5}+\mathrm{c}
$$

where, $K_{p}$ is the intraparticle diffusion constant $\left(\mathrm{mg} \cdot \mathrm{g}^{-1} \cdot \mathrm{min}^{-0.5}\right)$ and ' $\mathrm{c}$ ' is a constant $\left(\mathrm{mg} \cdot \mathrm{g}^{-1}\right)$. Graph between $\mathrm{q}_{\mathrm{t}}$ versus $\mathrm{t}^{0.5}$ produces a straight line as shown in Fig. 8. $\mathrm{K}_{\mathrm{p}}$ and ' $\mathrm{c}$ ' are evaluated from slope and intercept, respectively, and are presented in Table 3. In the Weber and Morris model, 'c' represents boundary layer thickness $[10,28]$ and higher value indicates diffusion through this layer is the rate controlling step. The value of ' $\mathrm{c}$ ' is found to increase from 0.05 to $0.14 \mathrm{mg} \cdot \mathrm{g}^{-1}$ for SAd and from 0.06 to $0.35 \mathrm{mg} \cdot \mathrm{g}^{-1}$ in case of CAd with an increase in initial concentration from 10 to $100 \mathrm{mg} \cdot \mathrm{L}^{-1}$. This change in value is attributed to the internal mass transfer that becomes prominent at higher concentration and 
external mass transfer decreases subsequently [28]. Further, the values of $K_{p}$ at higher concentration is observed to be more than that at lower concentration. It lies in the range $0.29-0.82$ and $0.09-0.14$ $\mathrm{mg} \cdot \mathrm{g}^{-1} \cdot \mathrm{min}^{-0.5}$ for CAd and SAd, respectively, for an increase in initial concentration from 10 to 100 $\mathrm{mg} \cdot \mathrm{L}^{-1}$. It is also concluded that CAd offers larger boundary layer effect in comparison to SAd as clear from Table 4; dye molecules have to overcome this extra resistance before they actually get adsorbed on the surface of an adsorbent.
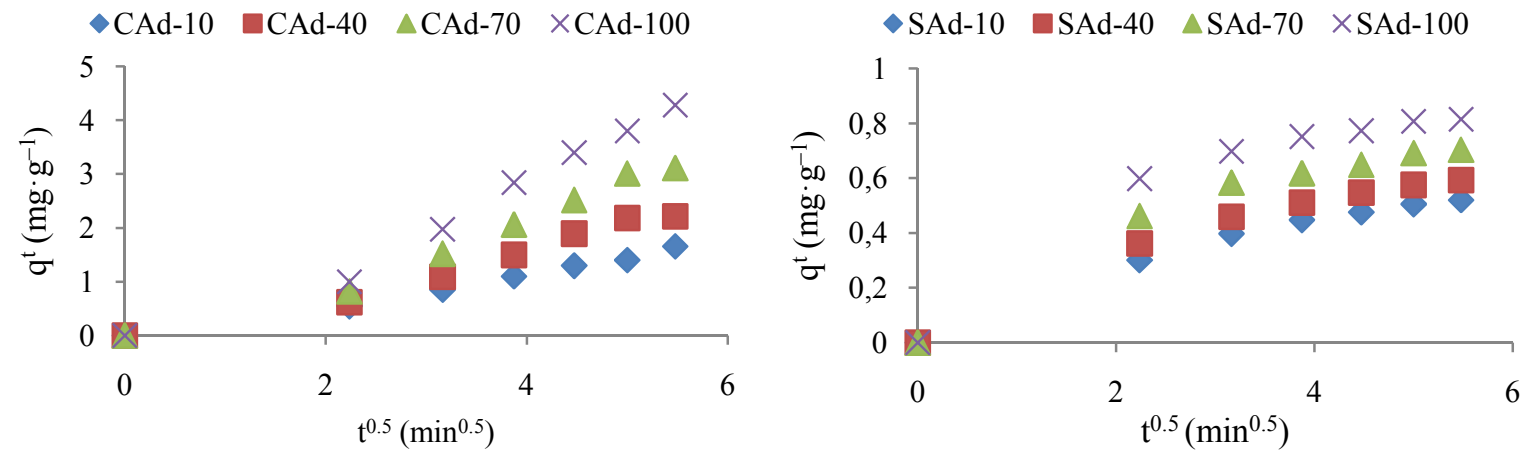

Fig. 8. Intra particle diffusion model for CAd and SAd for different initial concentrations $-10,40,70$ and $100 \mathrm{mg} \cdot \mathrm{L}^{-1}$ at $40^{\circ} \mathrm{C}$

Several thermodynamic parameters are determined from the basic relations as given below:

$$
\ln \mathrm{K}_{\mathrm{L}}=\frac{\Delta \mathrm{S}^{\circ}}{\mathrm{R}}-\frac{\Delta \mathrm{H}^{\circ}}{\mathrm{RT}}
$$

where,

$$
\Delta \mathrm{G}^{\circ}=\Delta \mathrm{H}^{\circ}-\mathrm{T} \Delta \mathrm{S}^{\circ}
$$

In above relations, $\mathrm{K}_{\mathrm{L}}$ is the distribution coefficient, $\mathrm{R}$ is the universal gas constant and $\mathrm{T}$ is the temperature in $\mathrm{K}$. The values for $\Delta \mathrm{H}^{\circ}$ and $\Delta \mathrm{S}^{\circ}$ are evaluated from slope and intercept, respectively, from the graph between $\ln \mathrm{K}_{\mathrm{L}}$ vs. 1/T.

Thermodynamic parameters for adsorption of malachite green on CAd and SAd

\begin{tabular}{|c|c|c|c|c|c|}
\hline \multirow{2}{*}{ Sample } & \multirow{2}{*}{$\begin{array}{c}\Delta \mathrm{H}^{\circ} \\
\left(\mathrm{kJ} \cdot \mathrm{mol}^{-1}\right)\end{array}$} & \multirow{2}{*}{$\begin{array}{c}\Delta \mathrm{S}^{\circ} \\
\left(\mathrm{J} \cdot \mathrm{mol}^{-1} \cdot \mathrm{K}^{-1}\right)\end{array}$} & \multicolumn{3}{|c|}{$\Delta \mathrm{G}^{\circ}\left(\mathrm{kJ} \cdot \mathrm{mol}^{-1}\right)$} \\
\hline & & & $303 \mathrm{~K}$ & $313 \mathrm{~K}$ & $323 \mathrm{~K}$ \\
\hline CAd & 100.26 & 330.22 & 0.20 & -3.09 & -6.40 \\
\hline SAd & 120.16 & 387.10 & 2.87 & -1.00 & -4.87 \\
\hline
\end{tabular}

Table 4

All the thermodynamic parameters evaluated from the above equations are presented in Table 4 . Temperature increment boosts negative free energy change of both solid substrates. The experimental value for $\Delta \mathrm{G}^{\circ}$ changes its trend from positive at $303 \mathrm{~K}$ to negative values at 313 and $323 \mathrm{~K}$ as clear from Table 4. It implies that the process was non-spontaneous at lower temperature andbecame spontaneous at higher temperature.Higher temperature enhances reaction rate; hence, $\Delta \mathrm{G}^{\circ}$ shows a negative trend [31,32]. Again, $\Delta \mathrm{H}^{\circ}$ for CAd and SAd is found to be 100.26 and $120.16 \mathrm{~kJ} \cdot \mathrm{mol}^{-1}$, respectively. The positive values indicate that the process is endothermic in nature with SAd showing higher value. This finding is in agreement with the above findings. For CAd and $S A d$, the value for $\Delta S^{\circ}$ is observed to be 330.22 and $387.10 \mathrm{~J} \cdot \mathrm{mol}^{-1} \cdot \mathrm{K}^{-1}$, respectively. The positive values of $\Delta \mathrm{S}^{\circ}$ reflect an increase in randomness at solid-solution interface as well as affinity of adsorbents for the dye molecules.

\section{Conclusions}

The potential of two adsorbents - CAd and SAd has been explored in this work. The following are the observations:

- Camelina and Sapindus seeds based adsorbents showed maximum adsorption for $\mathrm{pH} 6$ at $30^{\circ} \mathrm{C}$.

- Increased initial concentration resulted in higher removal percentage of dye from water solution. 


\section{Физическая химия}

- Both found to fit well in Langmuir model for isotherm.

- Rate is governed by the pseudo-first order kinetic model for CAd and SAd.

- Process spontaneity rose with temperature.

- Camelina being the softer precursor facilitated more escalation of volatiles during treatment with acid than Sapindus.

- CAd proved better adsorption capacities in comparison to SAd.

Hence, study illustrates the use of Camelina and Sapindus, for the production of adsorbents is quite promising as agricultural wastes are cheap, easily available and renewable sources.

\section{References}

1. Chowdhury S., Mishra R., Saha P., Kushwaha P. Adsorption Thermodynamics, Kinetics and Isosteric Heat of Adsorption of Malachite Green onto Chemically Modified Rice Husk. Desalin., 2011, vol. 265, pp. 159-168. DOI: 10.1016/j.desal.2010.07.047.

2. Gou Y., Yang S., Fu W., Qi J., Li R., Wang Z. Adsoprtion of Malachite Green on Micro- and Mesoporous Rice Husk-based Active Carbon. Dye. Pigment, 2003, vol. 56, pp. 219-229. DOI: $10.1016 / \mathrm{S} 0143-7208(02) 00160-2$.

3. Gupta V.K., Mittal A., Krishnan L., Gajbe V. Adsorption Kinetics and Column Operations for the Removal and Recovery of Malachite Green from Wastewater Using Bottom Ash. Sep. Purif. Technol, 2004, vol. 40, pp. 87-96. DOI:10.1016/j.seppur.2004.01.008.

4. Hameed B.H., El-Khaiary M.I. Kinetics and Equilibrium Studies of Malachite Green Adsorption on Rice Straw-derived Char. J. Hazard. Mater, 2008, vol. 153, pp. 701-708. DOI: 10.1016/j.jhazmat.2007.09.019.

5. Mittal A., Krishnan L., Gupta V.K. Removal and Recovery of Malachite Green from Wastewater Using an Agricultural Waste Material, De-oiled Soya. Sep. Purif. Technol, 2005, vol. 43, pp. 125-133. DOI: $10.1016 /$ j.seppur.2004.10.010.

6. Rahman I.A., Saad B., Shaidan S., Sya Rizal E.S. Adsorption Characteristics of Malachite Green on Activated Carbon Derived from Rice Husks Produced by Chemical-thermal Process. Bioresour. Technol, 2005, vol. 96, pp. 1578-1583. DOI: 10.1016/j.biortech.2004.12.015.

7. Santhi T., Manonmani S., Smitha T. Removal of Malachite Green from Aqueous Solution by Activated Carbon Prepared from the Epicarp of Ricinus communis by Adsorptionl. J. Hazard. Mater, 2010, vol. 179, pp. 178-186. DOI: 10.1016/j.jhazmat.2010.02.076.

8. Tian Y., Liu P., Wang X., Lin H. Adsorption of Malachite Green from Aqueous Solutions onto Ordered Mesoporous Carbons.Chem. Eng. J, 2011, vol. 171, pp. 1263-1269. DOI:10.1016/j.cej.2011.05.040.

9. Mittal A. Adsorption Kinetics of Removal of a Toxic Dye, Malachite Green, from Wastewater by Using Hen Feathers. J. Hazard. Mater, 2006, vol. 133, pp. 196-202. DOI: 10.1016/j.jhazmat.2005.10.017.

10. Ahmad M.A., Alrozi R. Removal of Malachite Green Dye from Aqueous Solution Using Rambutan Peel-based Activated Carbon: Equilibrium, Kinetic and Thermodynamic Studies. Chem. Eng. $J$, 2011, vol. 171, pp. 510-516. DOI: 10.1016/j.cej.2011.04.018.

11. Ahmad R., Kumar R. Adsorption Studies of Hazardous Malachite Green onto Treated Ginger Waste. J. Environ. Manage, 2010, vol. 91, pp. 1032-1038. DOI: 10.1016/j.jenvman.2009.12.016.

12. Akmil-Başar C., Önal Y., Kiliçer T., Eren D. Adsorptions of High Concentration Malachite Green by Two Activated Carbons Having Different Porous Structures. J. Hazard. Mater, 2005, vol. 127, pp. 73-80. DOI: 10.1016/j.jhazmat.2005.06.025

13. Kadirvelu K., Kavipriya M., Karthika C., Radhika M., Vennilamani N., Pattabhi S. Utilization of Various Agricultural Wastes for Activated Carbon Preparation and Application for the Removal of Dyes and Metal Ions from Aqueous Solutions. Bioresour. Technol, 2003, vol. 87, pp. 129-132. DOI: $10.1016 / \mathrm{S} 0960-8524(02) 00201-8$.

14. Crini G. Non-conventional Low-cost Adsorbents for Dye Removal: A review. Bioresour. Technol, 2006, vol. 97, pp. 1061-1085. DOI: 10.1016/j.biortech.2005.05.001.

15. Bekçi Z., Özveri C., Seki Y., Yurdakoç K.Sorption of Malachite Green on Chitosan Bead. J. Hazard. Mater, 2008, vol. 154, pp. 254-261. DOI: 10.1016/j.jhazmat.2007.10.021.

16. Bekçi Z., Seki Y., Cavas L. Removal of Malachite Green by Using an Invasive Marine Alga Caulerpa racemosa Var. cylindracea. J. Hazard. Mater, 2009, vol. 161, pp. 1454-1460. DOI: 10.1016/j.jhazmat.2008.04.125. 
17. Hameed B.H., El-Khaiary M.I. Batch Removal of Malachite Green from Aqueous Solutions by Adsorption on Oil Palm Trunk Fibre: Equilibrium isotherms and Kinetic Studies. J. Hazard. Mater, 2008, vol. 154, pp. 237-244. DOI: 10.1016/j.jhazmat.2007.10.017.

18. Khattri S.D., Singh M.K. Removal of Malachite Green from Dye Wastewater Using Neem Sawdust by Adsorption. J. Hazard. Mater, 2009, vol. 167, pp. 1089-1094. DOI: $10.1016 /$ j.jhazmat.2009.01.101.

19. Nethaji S., Sivasamy A., Thennarasu G., Saravanan S. Adsorption of Malachite Green Dye onto Activated Carbon Derived from Borassus Aethiopum flower Biomass. J. Hazard. Mater, 2010, vol. 181, pp. 271-280. DOI: 10.1016/j.jhazmat.2010.05.008.

20. Önal Y., Akmil-Başar C., Eren D., Sarici-Özdemir Ç., Depci T. Adsorption Kinetics of Malachite Green onto Activated Carbon Prepared from Tunçbilek Lignite. J. Hazard. Mater, 2006, vol. 128, pp. 150-157. DOI: 10.1016/j.jhazmat.2005.07.055.

21. Wang X.S., Zhou Y., Jiang Y., Sun C. The Removal of Basic Dyes from Aqueous Solutions Using Agricultural By-products. J. Hazard. Mater, 2008, vol. 157, pp. 374-385. DOI: 10.1016/j.jhazmat.2008.01.004.

22. Zhang J., J. Li J., J. Zhang J., Jing Y. Adsorption of Malachite Green from Aqueous Solution onto Carbon Prepared from Arundo Donax Root. J. Hazard. Mater, 2008, vol. 150, pp. 774-782. DOI: $10.1016 / \mathrm{j} . j$ hazmat.2007.05.036.

23. Hameed B.H., El-Khaiary M.I. Equilibrium, Kinetics and Mechanism of Malachite Green Adsorption on Activated Carbon Prepared from Bamboo by $\mathrm{K}_{2} \mathrm{CO}_{3}$ Activation and Subsequent Gasification with $\mathrm{CO}_{2}$. J. Hazard. Mater, 2008, vol. 157, pp. 344-351. DOI: $10.1016 /$ j.jhazmat.2007.12.105.

24. Sharon M., Soga T., Afre R., Sathiyamoorthy D., Dasgupta K., Bhardwaj S., Sharon M., Jaybhaye S. Hydrogen Storage by Carbon Materials Synthesized from Oil Seeds and Fibrous Plant Materials. Int. J. of Hy. En, 2007, vol. 32, pp. 4238-4249.DOI: 10.1016/j.ijhydene.2007.05.038.

25. Uğurlu M., Kula I., Karaoğlu M.H., Arslan Y. Removal of Ni(II) Ions from Aqueous Solutions Using Activated-carbon Prepared from Olive Stone by $\mathrm{ZnCl}_{2}$ Activation. Environ. Prog. Sustain Energy, 2009, vol. 28, pp. 547-557. DOI: 10.1002/ep.10358.

26. Tan I.A.W., Ahmad A.L., Hameed B.H. Adsorption Isotherms, Kinetics, Thermodynamics and Desorption Studies of 2,4,6-Trichlorophenol on Oil Palm Empty Fruit Bunch-based Activated Carbon. J. Hazard. Mater, 2009, vol. 164, pp. 473-482. DOI:10.1016/j.jhazmat.2008.08.025.

27. Chowdhury S., Saha P. Sea Shell Powder as a New Adsorbent to Remove Basic Green 4 (Malachite Green) from Aqueous Solutions: Equilibrium, Kinetic and Thermodynamic Studies. Chem. Eng. J, 2010, vol. 164, pp. 168-177. DOI: 10.1016/j.cej.2010.08.050.

28. Ghaedi M., Ansari A., Habibi M.H., Asghari A.R. Removal of Malachite Green from Aqueous Solution by Zinc Oxide Nanoparticle Loaded on Activated Carbon: Kinetics and Isotherm Study. J. Ind. Eng. Chem, 2014, vol. 20, pp. 17-28. DOI: 10.1016/j.jiec.2013.04.031.

29. Tang H., Zhou W., Zhang L. Adsorption Isotherms and Kinetics Studies of Malachite Green on Chitin Hydrogels. J. Hazard. Mater, 2012, vol. 209-210, pp. 218-225. DOI: 10.1016/j.jhazmat.2012.01.010.

30. Baek M.H., Ijagbemi C.O., O S.J., Kim D.S. Removal of Malachite Green from Aqueous Solution Using Degreased Coffee Bean. J. Hazard. Mater, 2010, vol. 176, pp. 820-828. DOI: $10.1016 / j$.jhazmat.2009.11.110.

31. Namasivayam C., Kavitha D. Removal of Congo Red from Water by Adsorption onto Activated Carbon Prepared from Coir Pith, an Agricultural Solid Waste. Dyes and Pigm., 2002, vol. 54, pp. 47-58. DOI: $10.1016 / \mathrm{S} 0143-7208(02) 00025-6$.

32. Ahmad M.A., Alrozi R. Removal of Malachite Green Dye from Aqueous Solution Using Rambutn peel-based Activated Carbon: Equilibrium, Kinetic and Thermodynamic Studies. Chem. Engg. J., 2011, vol. 171, pp. 510-516. DOI: 10.1016/j.cej.2011.04.018.

Sunanda Sharma, Assistant Professor, Chemical Engineering Department, DCRUST, Murthal, India, sunanda9@gmail.com

K.K. Pant, Professor, Chemical Engineering Department, IIT, Delhi, India, kkpant@chemical.iitd.ac.in

D.P. Tiwari, Professor, Chemical Engineering Department, DCRUST, Murthal, India, dptiwari3@gmail.com

Received 15 February 2016 


\title{
ИССЛЕДОВАНИЕ ПЕРИОДИЧЕСКОЙ АДСОРБЦИИ ПРИ УДАЛЕНИИ КРАСИТЕЛЯ МАЛАХИТОВОГО ЗЕЛЕНОГО ИЗ СТОЧНОЙ ВОДЫ С ИСПОЛЬЗОВАНИЕМ СОРБЕНТА НА ОСНОВЕ БИОМАССЫ
}

\author{
Сунанда Шарма', К.К. Пант ${ }^{2}$, Д.П. Тивари ${ }^{1}$ \\ ${ }^{1}$ Университет науки и технологий Динбандху Чхоту Рам, Мертал, Индия \\ ${ }^{2}$ Индийский институт технологии, Дели, Индия
}

Исследована адсорбция красителя малахитового зеленого над адсорбентами (Ad), полученными из скорлупы семян сапиндуса (S) и растения Camelina (C) после обработки серной кислотой. Изучено влияние на периодическую адсорбцию обоих адсорбентов различных параметров, таких как $\mathrm{pH}$, время, начальная концентрация, температура. Найдено, что изотермы для обоих адсорбентов лучше всего соответствуют модели Ленгмюра. Коэффициент разделения $\left(\mathrm{R}_{\mathrm{L}}\right)$ свидетельствует об эффективной адсорбции. Скорость адсорбции кинетически отвечает псевдопервому порядку. Модель диффузии внутрь частиц облегчает понимание массопереноса при адсорбции молекул красителя. Термодинамический анализ на обоих $\mathrm{Ad}$ показал самопроизвольность процессов при повышенной температуре. Проведенное сравнительное исследование демонстрирует большую адсорбционную емкость CAd по сравнению с SAd.

Ключевые слова: адсорбиия, малахитовый зеленый, сапиндус, Caтеlina.

Поступила в редакцию 15 февраля 2016 2.

\section{ОБРАЗЕЦ ЦИТИРОВАНИЯ}

Sunanda Sharma. Batch adsorption studies for malachite green dye removal from waste water using biomass based adsorbent / Sunanda Sharma, K.K. Pant, D.P. Tiwari // Вестник ЮУрГУ. Серия «Химия». - 2016. - Т. 8, № 2. C. 51-60. DOI: 10.14529/chem160206

\section{FOR CITATION}

Sunanda Sharma, Pant K.K., Tiwari D.P. Batch Adsorption Studies for Malachite Green Dye Removal from Waste Water Using Biomass Based Adsorbent. Bulletin of the South Ural State University. Ser. Chemistry. 2016, vol. 8, no. 2, pp. 51-60. DOI: 10.14529/chem160206 